\title{
Sistem Informasi Perpustakaan Berbasis Web pada SMK Karya Bhakti Purbalingga (SIPUS-KB)
}

\author{
Riyan Latifahul Hasanah ${ }^{1}$, Rizka Nurul Khasanah², \\ Fajar Sarasati ${ }^{3}$, Rousyati ${ }^{4}$, Qudsiah Nur Azizah ${ }^{5}$ \\ 1,2,4,5 Fakultas Teknik dan Informatika, Universitas Bina Sarana Informatika \\ ${ }^{3}$ Program Studi Sistem Informasi, STMIK Nusa Mandiri \\ riyan.rlt@bsi.ac.id
}

\begin{abstract}
Abstrak
Perpustakaan merupakan salah satu fasilitas yang dimiliki lembaga pendidikan. Penyelenggaraan perpustakaan sekolah menjadi sumber referensi utama bagi para siswa dan guru dalam mendapatkan materi-materi pelajaran. Layanan perpustakaan yang ideal harus mengacu pada kebutuhan dari pemustaka, mengikuti perkembangan teknologi informasi dan layanan prima. SMK Karya Bhakti Purbalingga merasa perlu untuk memanfaatkan perkembangan teknologi informasi dalam pelayanan perpustakaan untuk mendukung pelayanan perpustakaan yang mudah dan cepat, serta dapat memberikan kemudahan bagi pustakawan dalam proses pengolahan data. Pembaruan sistem baru dengan teknologi informasi berbasis web dilakukan dengan membangun aplikasi SIPUS-KB. Metode yang digunakan pada pengembangan perangkat lunak ini adalah model waterfall yang terdiri dari analisa kebutuhan, desain, pembuatan kode program, pengujian dan pemeliharaan. Aplikasi SIPUS-KB mampu memberikan kemudahan bagi pengunjung untuk memperoleh informasi serta memudahkan pustakawan dalam mengakses data-data dan dalam pembuatan laporan.
\end{abstract}

Kata Kunci : Sistem Informasi, Perpustakaan, Website, Waterfall

\section{Pendahuluan}

Perpustakaan merupakan salah satu fasilitas yang dimiliki lembaga pendidikan. Dalam dunia pendidikan, perpustakaan berfungsi sebagai sarana informasi yang diperlukan sebagai sumber belajar maupun laboratorium belajar yang memungkinkan para tenaga pendidik dan peserta didik meningkatkan kualitasnya (Rokan, 2017).

Penyelenggaraan perpustakaan sekolah bukan hanya sebatas untuk mengumpulkan dan menyimpan bahanbahan pustaka, tetapi juga untuk menjadi sumber referensi utama bagi para siswa dan guru dalam mendapatkan materimateri pelajaran (Muliasar dkk., 2018).

Layanan perpustakaan yang menempatkan kepuasan pemustaka merupkan tolak ukuran dari capaian perpustakaan. Layanan perpustakaan yang ideal harus mengacu pada kebutuhan dari pemustaka, mengikuti perkembangan teknologi informasi dan pemberian layanan yang prima (Saputra dkk., 2019).

SMK Karya Bhakti Purbalingga merupakan salah satu institusi pendidikan di Kabupaten Purbalingga, Jawa Tengah. Salah satu fasilitas yang dimiliki sekolah ini adalah perpustakaan yang melayani siswanya dalam penyediaan jasa peminjaman buku dan kegiatan yang berhubungan dengan pembelajaran. Namun selama ini kegiatan pelayanan di perpustakaan masih dilakukan secara manual.

Besarnya minat siswa untuk mendapatkan informasi dan meminjam buku di perpustakaan SMK Kharya Bhakti memunculkan gagasan bagi institusi untuk memanfaatkan perkembangan teknologi informasi dalam pelayanan perpustakaan. Dengan pengelolaan perpustakaan berbasis teknologi informasi, diharapkan dapat mendukung pelayanan perpustakaan yang mudah dan cepat, serta dapat memberikan kemudahan bagi pustakawan dalam proses pengolahan data.

Berdasarkan permasalahan tersebut maka diusulkan adanya pembaruan sistem lama ke sistem yang baru dengan teknologi informasi berbasis web, dengan membangun aplikasi SIPUS-KB atau 
Sistem Informasi Perpustakaan Berbasis Web pada SMK Karya Bhakti Purbalingga.

Tujuan dari penelitian ini adalah untuk merancang sebuah sistem informasi perpustakaan berbasis web untuk menunjang pelayanan di perpustakaan SMK Karya Bhakti Purbalingga, seperti memudahkan akses data dan informasi bagi siswa dan pengunjung, memudahkan pustakawan dalam melakukan pengolahan data dan dalam memberikan pelayanan, serta sebagai media kritik dan saran yang dapat menjadi bahan evaluasi bagi pihak sekolah dalam mengembangkan sarana dan prasarana sekolah.

Sebagai fokus permasalahan, penulis membatasi permasalahan yang akan dijelaskan yaitu:

1. Proses pengolahan data yang meliputi: data pustakawan, data anggota perpustakaan termasuk sistem pendaftaran anggota dan pencetakan kartu anggota, serta data koleksi buku.

2. Proses peminjaman dan pengembalian buku dengan ketentuan denda yang harus dibayar oleh anggota perpustakaan apabila terjadi keterlambatan pengembalian buku.

3. Sistem informasi laporan dan pencetakan laporan yang dilakukan pada periode tertentu yang terdiri dari: laporan peminjaman, laporan pengembalian buku beserta denda yang dibayarkan, laporan denda yang di peroleh dalam periode tertentu, serta laporan pengunjung perpustakaan.

4. Fasilitas tambahan berupa absen kunjungan perpustakaan, buku tamu, dan juga layanan $e$-book.

\section{Landasan Teori}

\section{Sistem Informasi}

Menurut O’Brian (Yakub, 2012), “Sistem informasi merupakan kombinasi teratur dari orang-orang, perangkat keras (hardware), perangkat lunak (software), jaringan komunikasi, dan sumber daya data yang mengumpulkan, mengubah, dan menyebarkan informasi dalam sebuah organisasi”.

\section{Website}

Website merupakan kumpulan dari halaman-halaman yang berhubungan dengan file-file lain yang saling terkait (Mubarak dkk., 2017).

Website juga dapat diartikan sebagai suatu kumpulan halaman yang menampilkan berbagai macam informasi seperti teks, data, gambar diam ataupun bergerak, animasi, suara, video maupun gabungan dari semuanya, baik itu yang bersifat statis maupun yang dinamis, serta membentuk satu rangkaian bangunan yang saling berkaitan dimana masing-masing dihubungkan dengan jaringan halaman atau hyperlink (Agus dkk., 2017).

\section{Perpustakaan}

Perpustakaan adalah salah satu unit kerja untuk mengatur, mengelola, menyimpan, dan mengumpulkan koleksi bahan pustaka secara sistematis untuk digunakan oleh pemakai sebagai sumber informasi sekaligus sebagai sarana belajar yang menyenangkan (Irviani dan Oktaviana, 2017).

\section{Model Pengembangan Perangkat Lunak}

Salah satu model pengembangan perangkat lunak atau Software Development Life Cycle (SDLC) yaitu model waterfall atau air terjun. Model ini sering juga disebut model sekuensial linier (sequential linier) atau alur hidup (classic life cycle). Model air terjun menyediakan pendekatan alur hidup perangkat lunak secara sekuensial atau terurut dimulai dari analisis, desain, pengkodean, pengujian, dan tahap pendukung (support) (Rosa dan Shalahuddin, 2013).

Berikut adalah gambar model air terjun:

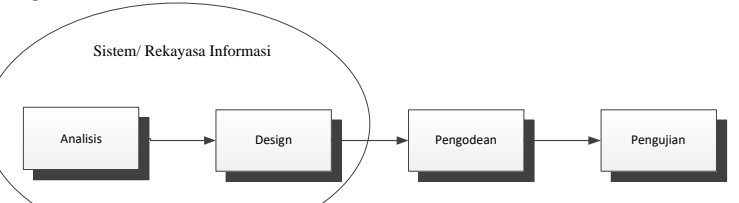

Sumber: (Rosa dan Shalahuddin, 2013) Gambar 1. Ilustrasi Model Waterfall

\section{Black Box Testing}

Black box testing ialah pengujian untuk mengetahui apakah semua fungsi 
perangkat lunak telah berjalan semestinya sesuai kebutuhan fungsional yang telah didefinisikan. Metode black box testing hanya melihat keluaran dari sistem tanpa memikirkan detail dalam sistem. Tujuan dari metode black box adalah mencari kesalahan pada fungsi yang hilang, kesalahan interface, struktur data performansi, inisialisasi dan tujuan akhir (Melati dkk., 2018).

\section{Metode Penelitian}

Metode yang digunakan pada pengembangan sistem informasi ini menggunakan model waterfall yang terbagi menjadi lima tahapan yaitu:

\section{Analisa Kebutuhan}

Pada tahap ini penulis melakukan analisa kebutuhan dengan melakukan riset di SMK Karya Bhakti. Dari hasil riset diperoleh kebutuhan-kebutuhan sistem dalam pembuatan aplikasi ini.

2. Desain

Dalam tahap ini dilakukan desain sistem yang difokuskan pada empat atribut yaitu struktur data, aritektur perangkat lunak, rancangan antarmuka dan prosedur pengkodean.

3. Pembuatan Kode Program

Pada tahap ini, desain diterapkan ke dalam bentuk serangkaian kode desain. Kode-kode tersebut disusun, sehingga membentuk suatu program berdasarkan desain yang telah dibuat. Kode program yang digunakan antara lain HMTL, PHP, CSS dan Javascript.

4. Pengujian

Setelah program selesai dibuat, maka selanjutnya proses pengujian. Tahap ini dilakukan guna mengetahui dan meminimalisir kesalahan (error) agar hasil keluaran yang ditampilkan dapat sesuai dengan yang diharapkan.

5. Pemeliharaan

Dalam tahap ini, program sudah dapat digunakan. Kemudian dilakukan pengecekan dan evaluasi secara rutin dengan rentang waktu yang sudah ditentukan. Dapat dimungkinkan terdapat penambahan, pengurangan atau pengubahan beberapa desain dan struktur program.

Sedangkan teknik pengumpulan data yang digunakan penulis dalam penelitian ini adalah:

\section{Observasi}

Pengumpulan data dan informasi yang dilakukan dengan cara melakukan penelitian pada perpustakaan SMK Karya Bhakti serta mengamati sistem yang sedang berjalan di perpustakaan tersebut.

2. Wawancara

Pengumpulan data dengan cara melakukan dialog secara langsung dengan pustakawan di SMK Karya Bhakti.

3. Studi Pustaka

Dalam metode ini penulis melengkapi informasi yang digunakan sebagai bahan referensi dengan mencari literatur buku dan jurnal di internet.

\section{Hasil Dan Pembahasan \\ Analisa Kebutuhan}

Analisa kebutuhan merupakan sebuah proses untuk mendapatkan informasi apa saja diperlukan dalam pembuatan website. Analisa kebutuhan terdiri dari kebutuhan pengguna dan kebutuhan sistem, sebagai berikut:

1. Analisa kebutuhan pengguna

Dalam website perpustakaan SMK Karya Bhakti ini terdapat 2 macam pengguna yaitu:

a. Pustakawan

Pustakawan merupakan pengguna yang dapat melakukan pengolahan data, baik itu berhubungan dengan website seperti menambah, mengubah dan menghapus konten yang ada di website, maupun melakukan kegiatan yang berkaitan dengan kegiatan perpustakaan. Beberapa yang dibutuhkan oleh pustakawan antara lain:

1) Pustakawan membutuhkan akses untuk mengelola halaman website.

2) Pustakawan membutuhkan sistem untuk mengelola data mengenai koleksi buku, koleksi e-book, kategori buku, daftar anggota dan proses peminjaman dan pengembalian buku.

3) Pustakawan membutuhkan informasi mengenai peminjaman dan pengembalian buku. 
4) Pustakawan membutuhkan sistem untuk mengelola pendaftaran anggota.

5) Pustakawan membutuhkan sistem untuk data absensi kunjungan.

6) Pustakawan membutuhkan sistem yang dapat mencetak semua laporan dari setiap data seperti data pengembalian, peminjaman, daftar koleksi buku, daftar anggota, dan laporan mengenai pemasukan dari denda anggota.

b. Pengunjung

Pengunjung merupakan pengguna yang dapat mengakses halaman utama web ini. Beberapa kebutuhan pengunjung diantaranya:

1) Pengunjung membutuhkan informasi mengenai daftar buku yang ada di perpustakaan SMK Karya Bhakti Purbalingga.

2) Pengunjung membutuhkan tambahan pengetahuan melalui sarana e-book.

3) Penggunjung membutuhkan layanan untuk absensi kunjungan perpustakaan.

4) Pengunjung apabila sudah menjadi anggota perpustakaan membutuhkan informasi mengenai status peminjaman buku dan informasi mengenai denda yang harus dibayarkan.

\section{Analisa Kebutuhan Sistem}

Beberapa kebutuhan sistem yang ada di website perpustaan pada SMK Karya Bhakti, di antaranya:

a. Pengolahan data

Dalam website perpustakaan pada SMK Karya Bhakti, terdapat beberapa data yang akan dikelola, diantaranya:

1) Data profil berupa sejarah, struktur organisasi dan informasi perpustakaan SMK Karya Bhakti Purbalingga.

2) Data anggota perpustakaan yang berisi informasi mengenai anggota yang telah terdaftar.

3) Data buku yang berisi informasi mengenai koleksi buku perpustakaan.
4) Data e-book yang berisi informasi mengenai koleksi $e$ book perpustakaan.

5) Data transaksi mengenai informasi peminjaman dan pengembalian buku.

6) Data absen kunjungan perpustakaan yang berisi informasi mengenai daftar pengunjung perpustakaan.

7) Pembuatan laporan dari setiap data seperti transaksi peminjaman buku, pengembalian buku dan total denda pengembalian buku dalam periode tertentu

b. Hak Akses

Hak akses yang terdapat pada website ini dibagi menjadi dua bagian, yaitu:

1) Pustakawan

Halaman yang dapat diakses oleh pustakawan antara lain: halaman kelola anggota, halaman kelola koleksi buku perpustakaan, halaman kelola $e$ book, halaman kelola transaksi peminjaman dan pengembalian buku, halaman kelola pustakawan, halaman kelola buku tamu, halaman kelola laporan dan halaman pengaturan.

2) Pengunjung

Halaman yang dapat diakses oleh pengunjung antara lain: halaman depan, halaman profil, halaman buku, halaman e-book, halaman absen kunjungan, halaman anggota, halaman tata tertib dan halaman buku tamu. Jika pengunjung sudah terdaftar menjadi anggota perpustakaan, maka anggota dapat mengakses status peminjaman buku.

c. Keamanan

Sistem keaman mencegah serangan dari pihak yang akan mengganggu berjalannya sistem. Beberapa sistem keamanan yang dibutuhkan antara lain: password yang di gunakan untuk login dienkripsi agar tidak terbaca oleh pihak luar serta 
terdapat sistem untuk ganti password untuk setiap pustakawan.

\section{Desain}

Desain terdiri dari rancangan antarmuka, rancangan basis data dan rancangan struktur navigasi, sebagai berikut:

1. Rancangan Antarmuka

Untuk memudahkan dalam perancangan tampilan web ini, maka rancangan antarmuka harus dibuat terlebih dahulu. Rancangan antarmuka website antara lain:

a. Rancangan Antarmuka Halaman Pustakawan

Halaman pustakawan adalah halaman yang digunakan untuk mengelola data perpustakaan dan isi dari website. Halaman ini muncul ketika pustakawan sudah melakukan login. Berikut adalah rancangan antarmuka halaman pustakawan:

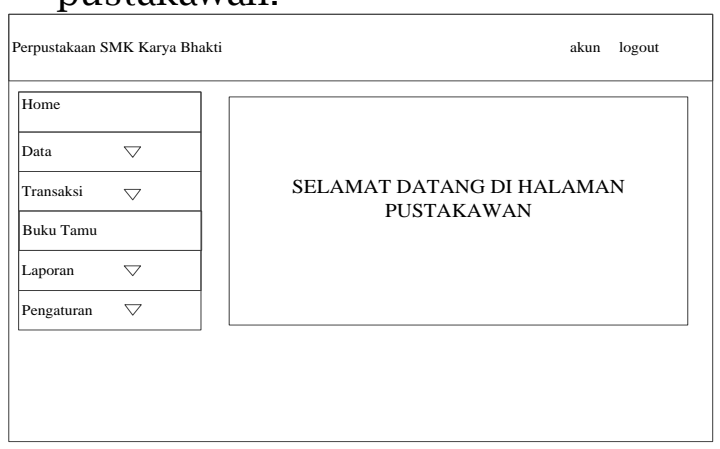

Gambar 2. Rancangan Antarmuka Halaman Pustakawan

b. Rancangan Antarmuka Halaman Utama Website Pengunjung

Halaman utama website adalah tampilan awal ketika pengguna mengakses alamat website Perpustakaan SMK Karya Bhakti Purbalingga. Berikut adalah rancangan antarmuka halaman pengunjung:

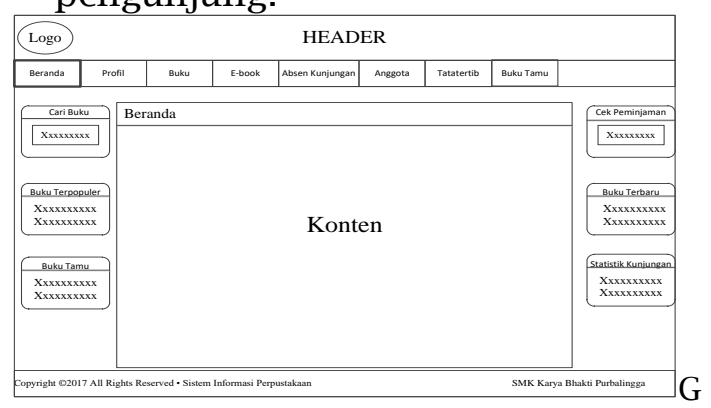

ambar 3. Rancangan Antarmuka Halaman

Utama Website
2. Rancangan Basis Data

Rancangan basis data digambarkan dengan Entity Relationship Diagram (ERD) dan Logical Relation Structure (LRS) sebagai berikut:

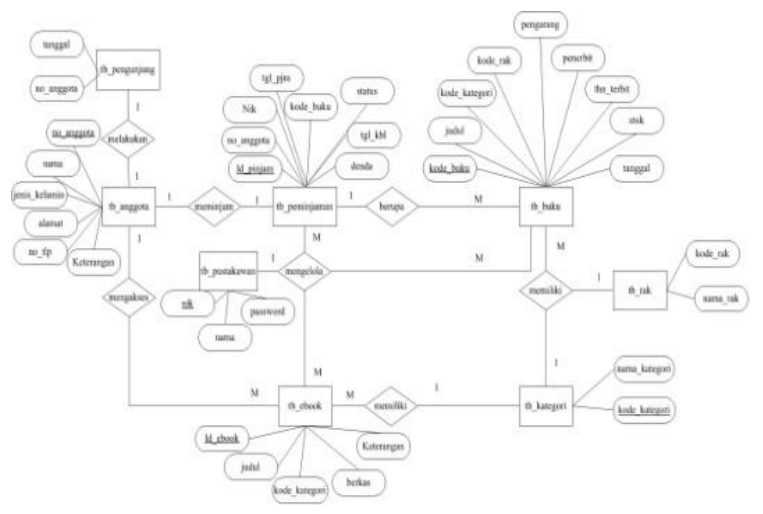

Gambar 4. Entity Relationship Diagram (ERD)

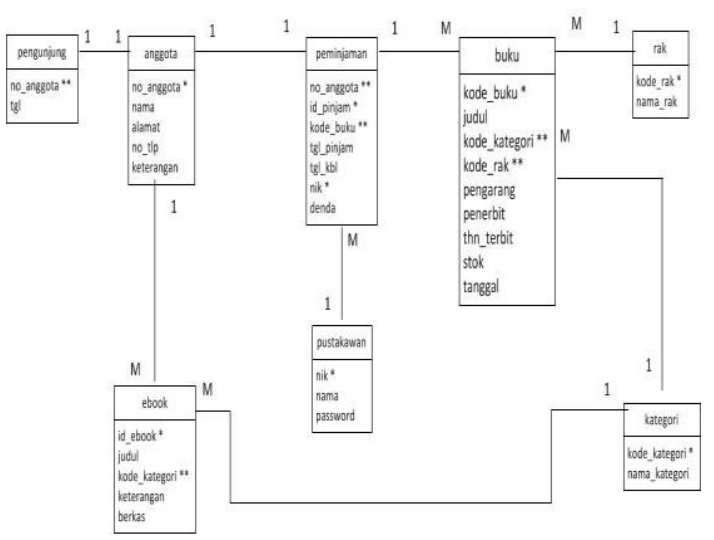

Gambar 5. Logical Relation Structure (LRS)

\section{Rancangan Struktur Navigasi}

Agar mempermudah dalam merancang sebuah web, maka perlu menggambarkan struktur navigasi website terlebih dahulu. Hal ini bertujuan untuk memperjelas proses perancangan tampilan web.
a. Rancangan
Struktur Navigasi
Pustakawan 


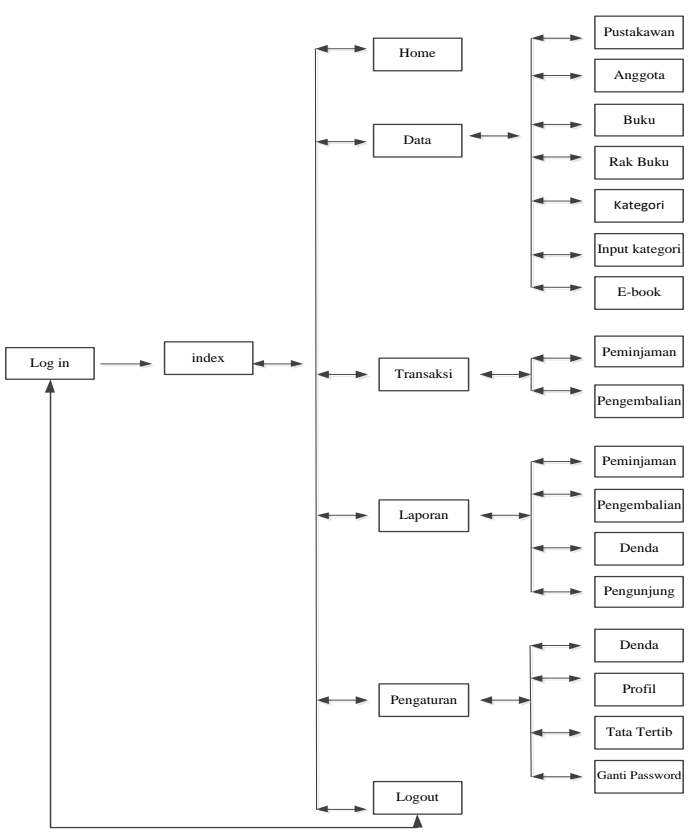

Gambar 6. Struktur Navigasi Pustakawan

b. Rancangan Struktur Navigasi Pengunjung

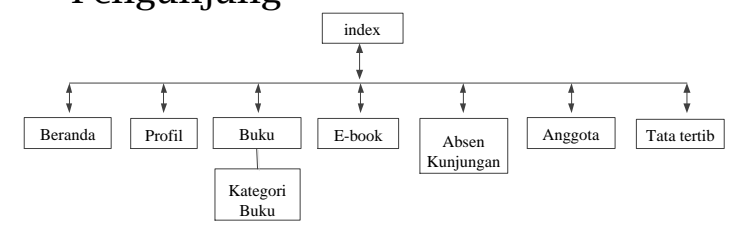

Gambar 7. Struktur Navigasi Pengunjung

\section{Implementasi}

Implementasi merupakan tahapan dimana rancangan yang telah dibuat diterapkan menjadi sistem utuh. Berikut implementasi dari website yang telah dibuat:

1. Halaman Pustakawan

Halaman ini hanya dapat diakses oleh pustakawan dan muncul ketika pustakawan telah login menggunakan username dan password yang benar. Halaman pustakawan digunakan untuk melakukan manajemen seluruh data yang ada pada website.

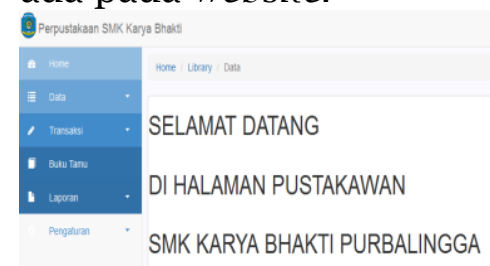

Gambar 8. Implementasi Halaman Pustakawan

\section{Halaman Transaksi Peminjaman}

Data peminjaman buku siswa diinput melalui halaman ini oleh pustakawan.

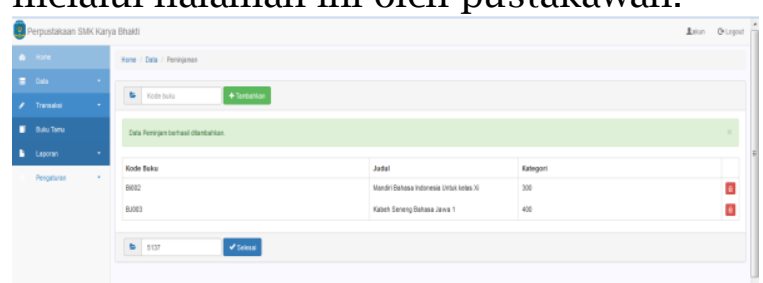

Gambar 9. Implementasi Halaman Transaksi Peminjaman

3. Halaman Transaksi Pengembalian

Data pengembalian buku siswa diinput melalui halaman ini oleh pustakawan. Ketika siswa terlambat mengembalikan buku maka akan tampil denda yang harus dibayarkan oleh siswa.

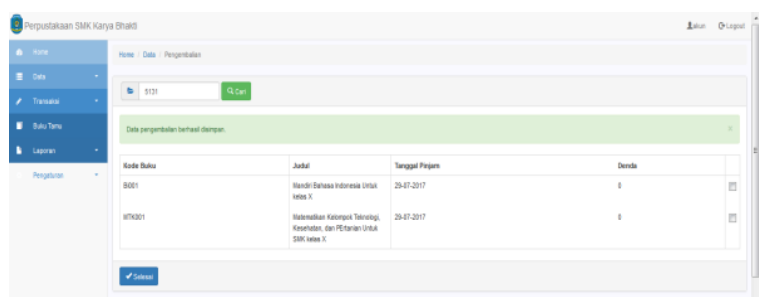

Gambar 10. Implementasi Halaman Transaksi Pengembalian

4. Halaman Data Anggota

Halaman ini dapat diakses oleh pustakawan untuk manajemen data anggota, seperti menambah data, mengedit data, menghapus data dan mencetak kartu anggota.

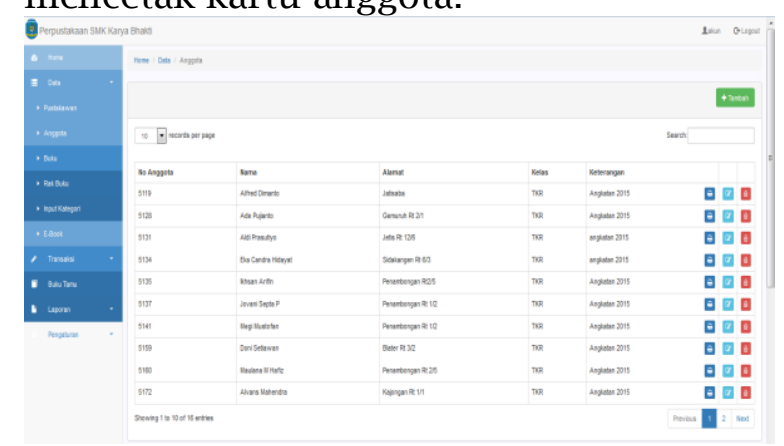

Gambar 11. Implementasi Halaman Data Anggota

5. Halaman Utama Website

Halaman ini dapat diakses oleh seluruh pengunjung. 


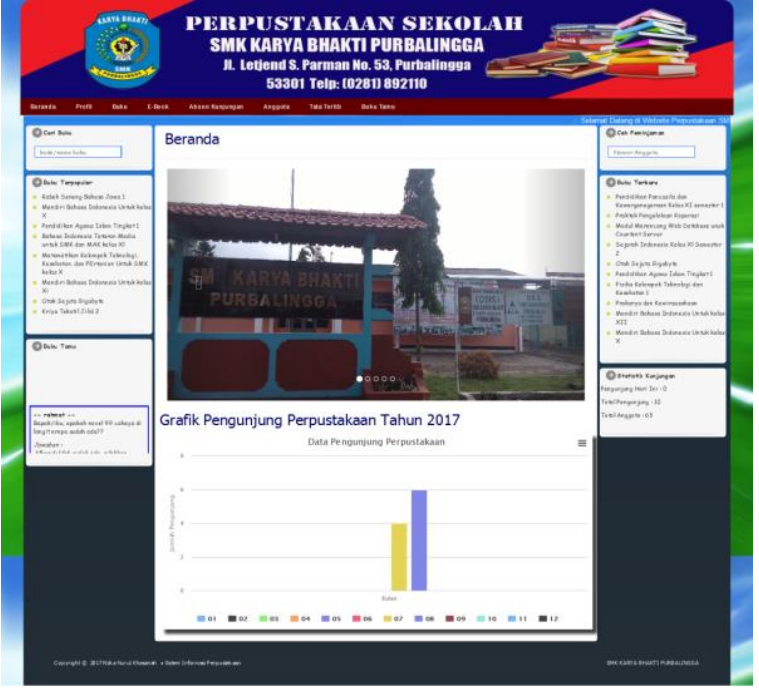

Gambar 12. Halaman Utama Website

\section{Halaman Buku}

Halaman buku berisi katalog yang menampilkan buku-buku yang dimiliki oleh perpustakaan SMK Karya Bhakti Purbalingga.

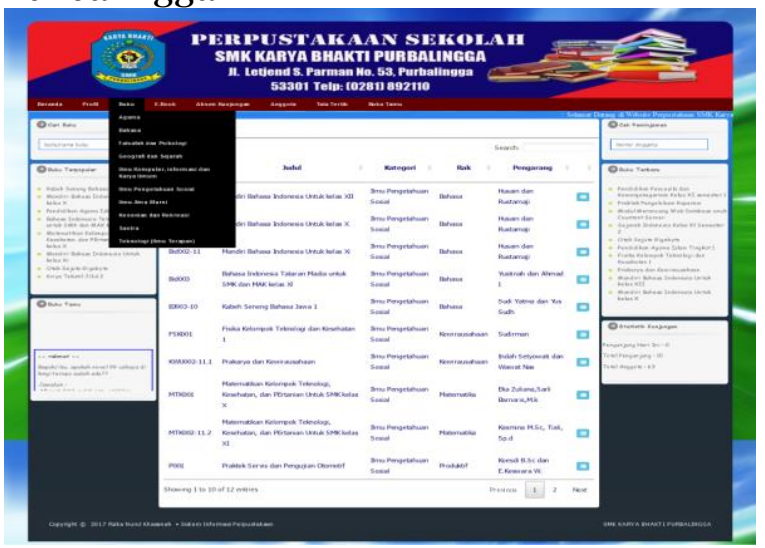

Gambar 13. Halaman Buku

\section{Halaman Absen Kunjungan}

Pengunjung perpustakaan dapat mengisi absen kunjungan melalui halaman absen kunjungan di website ini.

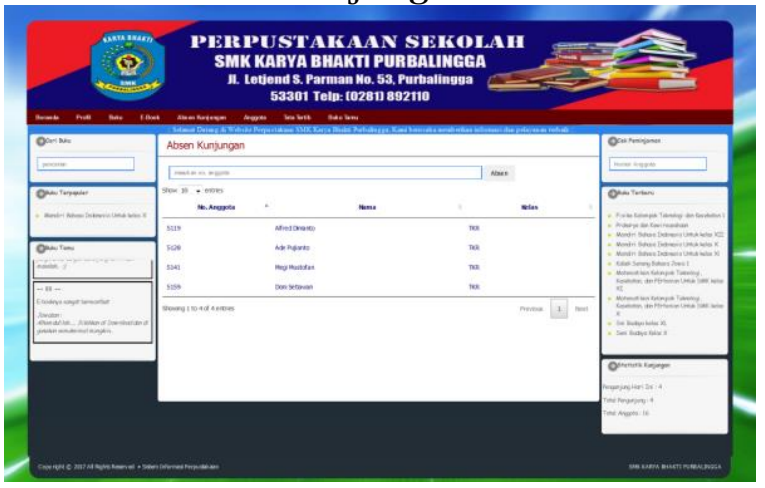

Gambar 14. Halaman Absen Kunjungan

\section{Pengujian Unit}

Pengujian dilakukan menggunakan teknik black box testing. Berikut adalah salah satu hasil pengujian pada halaman login pustakawan:

Tabel 1. Hasil Pengujian Black Box Testing Login Pustakawan

\begin{tabular}{|c|c|c|c|c|c|}
\hline $\begin{array}{l}\mathrm{N} \\
\mathbf{0}\end{array}$ & $\begin{array}{l}\text { Sekenario } \\
\text { Pengujian }\end{array}$ & Test Case & $\begin{array}{l}\text { Hasil Yang } \\
\text { Diharapkan }\end{array}$ & Hasil & $\begin{array}{l}\text { Kesim } \\
\text { pulan }\end{array}$ \\
\hline 1 & $\begin{array}{l}\text { Username, } \\
\text { password } \\
\text { tidak diisi, } \\
\text { kemudian } \\
\text { klik login }\end{array}$ & $\begin{array}{l}\text { Username: } \\
\text { (kosong) } \\
\text { Password: } \\
\text { (kosong) }\end{array}$ & $\begin{array}{l}\text { Sistem akan } \\
\text { menolak } \\
\text { dan akan } \\
\text { muncul "isi } \\
\text { pesan "isi } \\
\text { isian ini" }\end{array}$ & $\begin{array}{l}\text { Sesuai } \\
\text { harap- } \\
\text { an }\end{array}$ & Valid \\
\hline 2 & $\begin{array}{l}\text { Username } \\
\text { di isi dan } \\
\text { password } \\
\text { tidak di } \\
\text { isi, } \\
\text { kemudian } \\
\text { klik login }\end{array}$ & $\begin{array}{l}\text { username } \\
\text { : (isi) } \\
\text { Password: } \\
\text { (kosong) }\end{array}$ & $\begin{array}{l}\text { Sistem akan } \\
\text { menolak } \\
\text { dan akan } \\
\text { muncul "isi } \\
\text { pesan ini" } \\
\text { isian ini kolom } \\
\text { pada } \\
\text { password }\end{array}$ & $\begin{array}{l}\text { Sesuai } \\
\text { harap- } \\
\text { an }\end{array}$ & Valid \\
\hline 3 & $\begin{array}{l}\text { Username } \\
\text { tidak di isi } \\
\text { dan } \\
\text { password } \\
\text { di isi, } \\
\text { kemudian } \\
\text { klik login }\end{array}$ & $\begin{array}{l}\text { Username: } \\
\text { (kosong) } \\
\text { Password: } \\
\text { (isi) }\end{array}$ & $\begin{array}{l}\text { Sistem akan } \\
\text { menolak } \\
\text { dan akan } \\
\text { muncul "isi } \\
\text { pesan "is } \\
\text { isian ini" } \\
\text { pada kolom } \\
\text { username }\end{array}$ & $\begin{array}{l}\text { Sesuai } \\
\text { harap- } \\
\text { an }\end{array}$ & Valid \\
\hline 4 & $\begin{array}{l}\text { Username } \\
\text { di isi dan } \\
\text { password } \\
\text { di isi, } \\
\text { kemudian } \\
\text { klik login }\end{array}$ & $\begin{array}{l}\text { Username } \\
\text { : (isi) } \\
\text { Password: } \\
\text { (isi) }\end{array}$ & $\begin{array}{l}\text { Sistem akan } \\
\text { menerima } \\
\text { akses } \\
\text { pustakawan } \\
\text { \& } \\
\text { menampil- } \\
\text { kan } \\
\text { halaman } \\
\text { pustakawan }\end{array}$ & $\begin{array}{l}\text { Sesuai } \\
\text { harap- } \\
\text { an }\end{array}$ & valid \\
\hline
\end{tabular}

\section{Simpulan}

Berdasarkan pembahasan diatas, maka penulis menyimpulkan bahwa dengan adanya website perpustakaan SMK Karya Bhakti maka informasi dan data mengenai perpustakaan dapat lebih mudah diakses.

Selain itu website perpustakaan SMK Karya Bhakti yang dilengkapi dengan menu pencarian buku akan memudahkan pengunjung perpustakaan dalam mencari buku yang diinginkan. Anggota juga dapat mengetahui jangka waktu pengembalian buku yang dipinjam melalui menu cek status peminjaman.

Aplikasi SIPUS-KB juga memberikan kemudahan bagi pustakawan dalam mengakses data-data dan dalam membuat laporan setiap periode tertentu, karena data-data perpustakaan telah terintegrasi ke dalam sistem yang terkomputerisasi.

Bagi pihak sekolah, dengan adanya website ini maka kritik dan saran dari para pengunjung dapat diketahui lebih 
mudah melalui fasilitas buku tamu yang ada pada website.

\section{Daftar Pustaka}

Agus, I., Marisa, F., \& Wijaya, I. D. (2017). Sistem Pendukung Keputusan Penerimaan dan Penilaian Karyawan Warehouse dengan Aplikasi Web. Journal of Information Technology and Computer Science (JOINTECS), 1(2). Retrieved from http://publishingwidyagama.ac.id/ejournal-

v2/index.php/ jointecs/article/viewFile/413/404

Irviani, R., \& Oktaviana, R. (2017). Aplikasi Perpustakaan pada SMA N 1 Kelumbayan Barat Menggunakan Visual Basic. Journal TAM (Technology Acceptance Model), 8(1). Retrieved from http://ojs.stmikpringsewu.ac.id/ index.php/JurnalTam/article/viewFile/ 89/83

Melati, A., Ken, M., Kusuma, P. D., \& Nugrahaeni, R. A. (2018). Pengembangan Motif Karang Jenis Anacropora Forbesi pada Aplikasi Batik Berbasis Web. E-Proceeding of Engineering, 5(3), 6297-6304. Retrieved from https://libraryeprocee ding.telkomuniversity.ac.id/index.php/ engineering/article/viewFile/8067/795 9

Mubarak, Z. Y., Noor, E., Destyanto, F., Nugroho, K. T., Iqbal, M., Mustofa, \& Arif, A. M. (2017). Perancangan Sistem Informasi Kesehatan di Tingkat Posyandu Cilacap Selatan Kabupaten Cilacap. Seminar Nasional Teknologi Informasi Dan Multimedia, 5(1), 271$276 . \quad$ Retrieved from https://ojs.amikom.

ac.id/index.php/semnasteknomedia/ar ticle/view/1633

Muliasari, A., Danim, S., \& Anwar, S. (2018). Tata Kelola Perpustakaan Sekolah. Jurnal Manajer Pendidikan, 12(3). Retrieved from https://ejournal.unib.ac.id/index.php/ manajerpendidikan/article/view/5947

Rokan, M. R. (2017). Manajemen Perpustakaan Sekolah. Jurnal Iqra', 11(01), 88-100. Retrieved from http://jurnal.uinsu.ac.id/index.php/iqr a/article/view/795
Rosa, A. ., \& Shalahuddin, M. (2013). Rekayasa Perangkat Lunak Terstruktur dan Berorientasi Objek. Bandung: Informatika Bandung.

Saputra, A. A., Syafi'i, Zainuri, A., \& Ibrahim, D. (2019). Strategi Peningkatan Mutu Pelayanan Perpustakaan Madrasah Aliyah Negeri (MAN) 3 Palembang. Jurnal Intelektualita: Keislaman, Sosial, Dan Sains, 8(2). Retrieved from http://jurnal.radenfatah.ac.id/index.ph p/intelektualita/article/view/5460

Yakub. (2012). Pengantar Sistem Informasi. Yogyakarta: Graha Ilmu. 